\title{
Application of the Internet of Things (IoT) based digital platform for "Peduli, Keamanan, dan Ketertiban" (PEKERTI)
}

\section{Aplikasi platform digital sistem "Peduli, Keamanan, dan Ketertiban" (PEKERTI) berbasis Internet of Things (IoT)}

\author{
Irham Fadlika, Arif Nur Afandi, Langlang Gumilar, Muhammad Rizal Andriansyah, \\ Eka Mistakim, Achmad Syahrudin Fakhri, M. Ricko Gunawan \\ Departemen Teknik Elektro, Fakultas Teknik, Universitas Negeri Malang \\ Jl. Semarang No. 5 Malang, 65145, Indonesia
}

\author{
ARTICLE INFO: \\ Received: 2021-05-22 \\ Revised: 2021-07-22 \\ Accepted: 2021-11-03 \\ Keywords: \\ Android application, \\ Digital platform, \\ Internet of Things (IoT), \\ PEKERTI
}

\section{ABSTRACT}

This community service program is implemented in RT 09 RW 06 Penanggungan Village, Klojen District, Malang City. This is a housing estate that is located close to several campuses, making it vulnerable to being a crime target. In this program, we present an idea to solve this problem by creating an Internet of Things (IOT) based Android application "Peduli, Keamanan, Ketertiban" (PEKERTI). This system acts as a medium for partner residents to monitor their environmental conditions through installed CCTV cameras, exchange information and inform each other, to send voice messages to be broadcasted through loudspeakers if there are indications of danger or crime-prone conditions. This program relies on four main stages, namely analysis and question and answer, preparation of supporting equipment, PEKERTI application design, and evaluation design. The results showed several positive responses from the Penanggungan community who assessed the effectiveness of this activity, marked by increased enthusiasm, order, concern, security, and comfort.

(C) 2022 Abdimas: Jurnal Pengabdian Masyarakat Universitas Merdeka Malang This is an open access article distributed under the CC BY-SA 4.0 license (https://creativecommons.org/licenses/by-sa/4.0/)

How to cite: Fadlika, I., Afandi, A. N., Gumilar, L., Andriansyah, M. R., Mistakim, E., Fakhri, A. S., \& Gunawan, M. R. (2022). Application of the Internet of Things (IoT) based digital platform for "Peduli, Keamanan, dan Ketertiban" (PEKERTI). Abdimas: Jurnal Pengabdian Masyarakat Universitas Merdeka Malang, 7(1), 54-63.

https://doi.org/10.26905/abdimas.v7i1.5803

\section{PENDAHULUAN}

Menurunnya pendapatan hingga pemutusan hubungan kerja bagi sebagian besar masyarakat menyebabkan kejahatan menjadi potensi untuk memenuhi kebutuhan ekonomi (Sugiarti, 2014). Motif ekonomi menjadi penggerak utama bagi mayoritas individu untuk menjustifikasi keputusasaan akibat minimnya kesempatan dan meningkatnya persaingan mendapatkan lapangan pekerjaan, untuk menjadi pelaku kriminal (Dede et al., 2019). Selain itu, kondisi kesenjangan ekonomi dalam masyarakat juga menjadi penguat bagi seorang pelaku kejahatan untuk meraih kesempatan untuk mencuri barang berharga milik orang lain yang dengan tingkat ekonomi yang lebih tinggi (Tutrianto, 2018). Kedua poin yang telah 
disebutkan sebelumnya menjadikan kota-kota besar di Indonesia (Mufidah, 2021; Sutejo et al., 2020; Pramesti \& Suardana, 2019; Puspitasari et al., 2019) memiliki angka kejahatan yang relatif tinggi dan menggolongkan mereka sebagai daerah-daerah yang rawan terhadap potensi kejahatan.

Salah satu lingkungan yang rawan menjadi sasaran tindak kejahatan seperti pencurian dan perampokan adalah lingkungan warga RT 09 RW 06 Penanggungan Kecamatan Klojen Kota Malang. Lokasinya terletak di antara dua kampus utama Kota Malang yaitu Universitas Negeri Malang dan Universitas Brawijaya. Lingkungan ini mempunyai dua jalan keluar yang menyebabkan warga dan mahasiswa perantau dari wilayah lain mudah masuk dan keluar dari lingkungan ini. Beragam masyarakat yang melalui daerah ini ditambah belum ada kewaspadaan kolektif dan sistem pengamanan yang baik menjadikan lokasi ini menjadi sasaran utama bagi pelaku pencurian kendaraan bermotor. Beberapa upaya pemerintah dan pihak berwajib sebenarnya telah diusulkan untuk meminimalkan daerah dengan potensi resiko seperti ini dengan bentuk kemitraan antara kepolisian dan masyarat setempat (Mustolih, 2019) dan sosialisasi kewaspadaan masyarakat guna menjaga keamanan areanya (Purnomo, 2019; Zamroni \& Ghafur, 2016). Akan tetapi, upaya-upaya tersebut sangat terbatas jangkauannya dan masyakarat sering lengah sampai terjadinya tindak kejahatan, menyebabkan tingkat kriminalitas relatif tetap tinggi (Oktavia, 2020).

Salah satu alternatif upaya yang dapat dilakukan untuk memberikan rasa aman dan meningkatkan kewaspadaan bagi masyarakat di daerah rawan kejahatan yaitu dengan memanfaatkan teknologi (Al Rasyid et al., 2020). Dengan menggunakan perangkat monitoring yang terintegrasi, kejahatan dapat dicegah dan apabila terjadi, pelaku bisa segera teridentifikasi (Karinda et al., 2021; Tarwanto \& Arinal, 2021; Wardani et al., 2021; Doni, 2020; Ramayani et al., 2018; Gozali \& Basori, 2016). Berdasarkan contohcontoh tersebut, dalam tulisan ini, tim pengabdi menawarkan pemanfaatan teknologi berupa pembuatan platform digital aplikasi Android berbasis Internet of Things (IOT) guna memantau kegiatan warga selama 24 jam di lingkungan Penanggungan, Kota Malang. Pengawasan kegiatan ini menggunakan piranti kamera CCTV beserta pengeras suara di mana perangkat setempat dapat memberikan informasi atau mengingatkan warganya. Selain itu, terdapat fitur lain berupa broadcast di mana warga dapat berinteraksi satu sama lain untuk bertukar informasi terkait kondisi terkini di sekitar rumahnya atau di lingkungan Penanggungan. Secara singkat, aplikasi digital yang kami usulkan yaitu sistem Kepedulian, Keamanan, dan Ketertiban (PEKERTI) yang memiliki tujuan untuk menambah keamanan di wilayah Penanggungan, Kota Malang.

\section{METODE}

Kegiatan pengabdian ini bertumpu terhadap empat tahapan pokok yaitu: (1) Analisis dan tanya jawab; (2) Persiapan peralatan pendukung; (3) Perancangan Aplikasi PEKERTI; dan (4) Rancangan evaluasi.

\section{Analisis situasi dan tanya jawab}

Tahap ini berfokus pada kegiatan survei lokasi, pengumpulan data dari narasumber di sekitar lingkungan mitra, identifikasi masalah yang dihadapi mitra, sekaligus melakukan diskusi secara kolektif bersama perwakilan warga. Metode tanya jawab digunakan oleh tim pengabdi untuk memperoleh data yang lebih lengkap terkait permasalahan mitra, serta menjawab pertanyaan-pertanyaan mitra terkait kegiatan yang akan dilakukan, dan juga sekaligus menjadwalkan waktu yang tepat untuk melakukan pengabdian.

\section{Persiapan peralatan pendukung}

Pada tahap ini tim pengabdian melakukan survei secara menyeluruh di lingkungan mitra untuk menentukan dimana titik-titik strategis pemasangan kamera pengawas CCTV, menyiapkan peralatan penunjang yang dibutuhkan untuk instalasi, serta melakukan riset pembuatan aplikasi platform digital berbasis Internet of Things (IoT), serta kegiatan penunjang mulai dari koordinasi dengan instansi terkait, 
ABDIMAS: Jurnal Pengabdian Masyarakat Universitas Merdeka Malang

Volume 7, No 1, February 2022: 54-63

Kepala Desa/Lurah serta tokoh-tokoh masyarakat yang bersedia membantu dalam terlaksananya program pengabdian ini.

\section{Perancangan Sistem PEKERTI}

Perwujudan dari sistem PEKERTI yaitu piranti lunak yang berupa aplikasi android yang dapat di-install melalui smartphone sebagai sistem informasi (Yutanto et al., 2020) dan piranti keras berupa kamera pemantau yang ditempatkan di tempat-tempat yang strategis, pengeras suara yang terpasang sebagai sarana penyalur informasi, kemudian pemasangan server sebagai pusat data penyimpanan dan penyalur informasi. Gambar 4 menjelaskan metode realisasi dari sistem ini.

\section{Piranti keras (sistem monitoring CCTV)}

Berdasarkan Gambar 1, perangkat keras yang diusulkan dalam kegiatan ini terdiri atas seperangkat kamera CCTV, amplifier, dan pengeras suara (speaker). Kamera-kamera CCTV ini akan dipasang di beberapa titik krusial lalu lintas warga Penanggungan yang kemudian diintegrasikan dalam sebuah server. Selain itu, terdapat amplifier dan pengeras suara yang dapat digunakan oleh perangkat setempat untuk mengingatkan warga. Secara umum, cara kerja CCTV sama seperti kamera video tetapi pada penerapan ini ditujukan untuk menghalau potensi tindak kejahatan dan memantau aktivitas penghuni Penanggungan selama 24 jam.

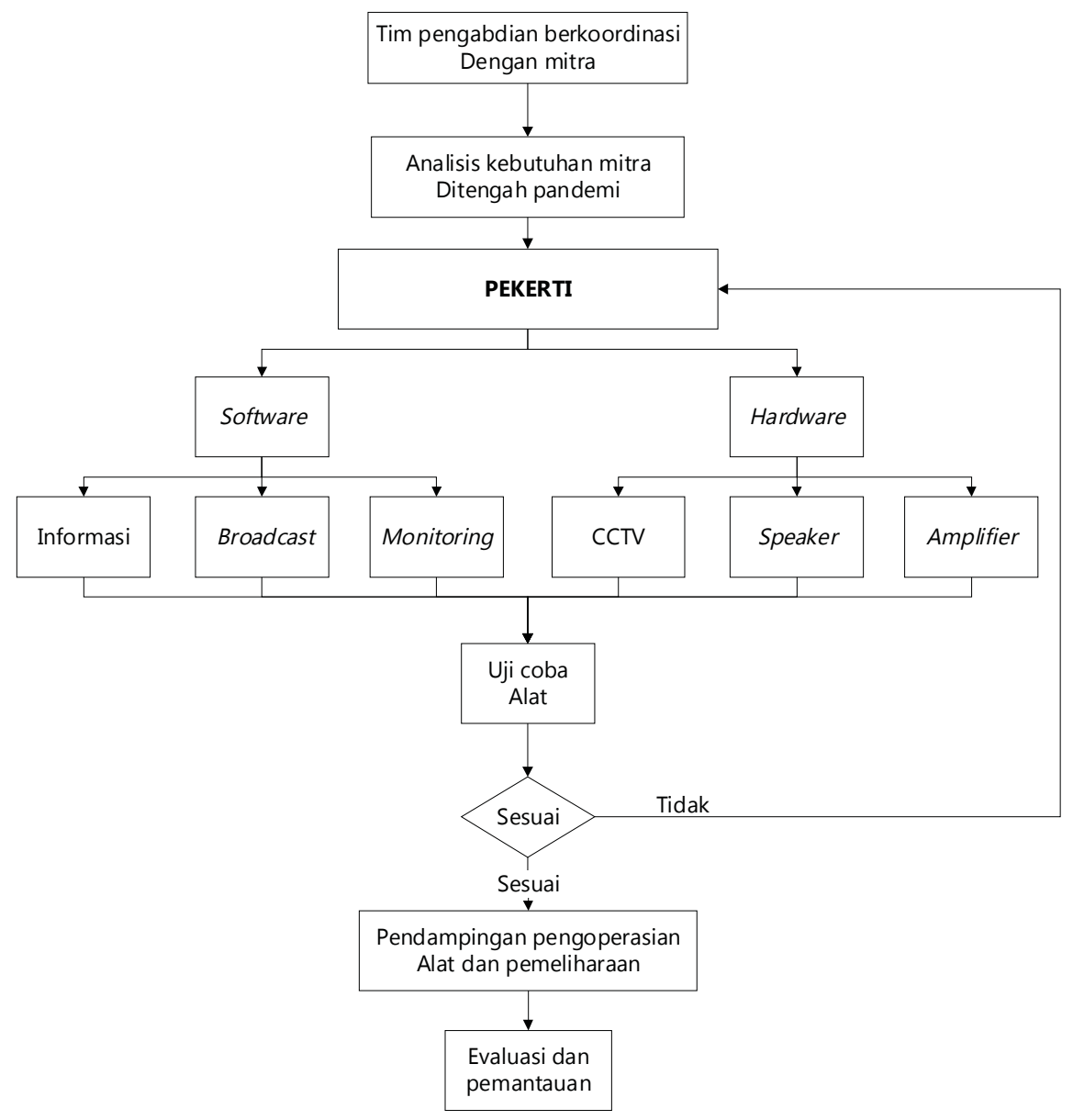

Gambar 1. Diagram alir metode desain dan implementasi PEKERTI 


\section{Piranti lunak (aplikasi Android PEKERTI)}

Berdasarkan uraian konfigurasi perangkat CCTV sebelumnya, poin ini akan menjelaskan piranti lunak yang berfungsi untuk memproses dan menampilkan data video yang dapat diakses dan ditindaklanjutioleh warga Penanggungan. Server yang telah terkoneksi dengan kamera-kamera CCTV yang telah terpasang mengirimkan data melalui jaringan internet untuk kemudian dapat diakses oleh warga melalui Aplikasi PEKERTI. Warga terlebih dahulu harus mengunduh dan meng-install aplikasi tersebut dan mengisikan data diri berupa nama, alamat, dan foto terbaru. Selain itu, perangkat desa misalnya, diberikan hak akses sebagai admin untuk mengetahui data warga dan mahasiswa perantau yang tinggal di Penanggungan, memberikan sandi terhadap warga yang akan bergabung dalam aplikasi ini. Di lain sisi, hak akses untuk bertukar informasi melalui pesan broadcast, monitoring CCTV, dan pengiriman sinyal atau tanda apabila indikasi kondisi yang berbahaya dapat digunakan oleh semua pengguna Aplikasi PEKERTI.

Sesuai Gambar 1, fitur-fitur utama dalam Aplikasi PEKERTI meliputi fitur informasi, fitur monitoring, dan fitur broadcast. Pertama, fitur informasi pada prinsipnya berfungsi sebagai media bagi warga untuk bertukar informasi ketika terkait warga kos yang datang dari luar kota, pemilik kos dapat segera memberitahukan kepada ketua RT dan warga lainnya untuk mengingatkan apabila terdapat kendaraan bermotor yang diparkir sembarangan. Fitur selanjutnya adalah monitoring atau pengawasan yang dapat diakses oleh semua warga yang telah memiliki dan terverifikasi dalam Aplikasi PEKERTI untuk memantau setiap kamera yang telah terpasang. Selama internet dan listrik tersedia, kamera pengawas CCTV akan bekerja penuh selama 24 jam dan dapat diakses melalui jarak jauh sehingga warga yang sedang bepergian atau tidak berada di area tersebut dapat memonitor kondisi lingkungannya melalui smartphone mereka. Fitur ketiga adalah fitur broadcast yang digunakan admin untuk memberikan pengumuman melalui pengeras suara yang dapat diakses melalui Aplikasi PEKERTI, prinsip kerjanya menggunakan pesan suara dari Aplikasi PEKERTI yang kemudian diterima oleh raspberry pie dan diproses ke amplifier dan pengeras suara yang dapat menjangkau semua wilayah di lingkungan mitra.

\section{Rancangan evaluasi}

Untuk mengukur tingkat keberhasilan program yang diusulkan oleh tim pengabdi, terdapat tiga kriteria utama yang kami gunakan sebagai acuan. Adapun kriteria tersebut meliputi aspek keberhasilan pelaksanaan kegiatan, keberhasilan dari pihak mitra, dan keberhasilan dari pihak pelaksana. Secara spesifik, penjelasan untuk masing-masing kriteria dijabarkan sebagai berikut: (1) Keberhasilan pelaksanaan kegiatan mencakup implementasi kegiatan pengabdian sesuai dengan waktu telah ditetapkan; (2) Keberhasilan dari pihak mitra berupa terciptanya lingkungan mitra yang peduli dengan sesama warga, terciptanya keamanan di tengah pandemi, dan tertibnya masyarakat dalam menjalankan protokol kesehatan dari pemerintah; (3) Keberhasilan dari pihak pelaksana menitikberatkan pada pemberian penjelasan serta bantuan yang dapat membantu warga Penanggungan dalam menggunakan Aplikasi PEKERTI secara baik, memberikan penjelasan tentang perawatan perangkat CCTV, serta sistem monitoring yang beroperasi selama 24 jam.

\section{HASIL DAN PEMBAHASAN}

Kegiatan pembuatan aplikasi Platform Digital Sistem Peduli, Keamanan, dan Ketertiban (PEKERTI) Berbasis Internet of Things (loT) ini dilakukan pada Minggu, 28 Juni 2020 pukul 08.00-15.00 WIB di lingkungan warga RT 09 RW 06 Penanggungan Kecamatan Klojen Kota Malang. Kegiatan pengabdian ini dibagi dalam tiga tahap pelaksanaan yaitu tahap pembukaan, tahap persiapan peralatan, dan tahap instalasi. 
ABDIMAS: Jurnal Pengabdian Masyarakat Universitas Merdeka Malang

Volume 7, No 1, February 2022: 54-63

\section{Tahap pembukaan}

Tahap ini dilakukan pada pukul 08.00-08.30 WIB. Kegiatan diawali dengan sambutan dari ketua tim pengabdian dan sambutan Ketua RT, kegiatan doa bersama dengan harapan kegiatan dapat berjalan dengan lancar dari awal pelaksanaan sampai dengan akhir. Pada tahap ini juga tim pengabdian menjelaskan rangkaian kegiatan kepada mitra dan warganya tentang apa saja yang akan dilakukan mulai dari pemasangan CCTV, pengeras suara sampai dengan penggunaan Aplikasi PEKERTI secara singkat beserta manfaat dari kegiatan ini kepada mitra dan warganya. Dokumentasi kegiatan pembukaan dapat dilihat pada Gambar 2.

\section{Tahap persiapan alat dan bahan}

Setelah acara pembukaan, kegiatan selanjutnya yaitu penyemprotan disinfektan ke lingkungan dan menyiapkan peralatan pendukung untuk kegiatan pemasangan CCTV. Alat dan bahan yang disiapkan berupa tangga, bor listrik, palu, paku, kabel, kamera CCTV, pengeras suara, control room, dan peralatan pendukung lainya. Pada tahap ini juga tim memastikan kembali titik-titik yang akan dilakukan instalasi kamera CCTV. Kegiatan persiapan ini ditunjukan oleh Gambar 3.
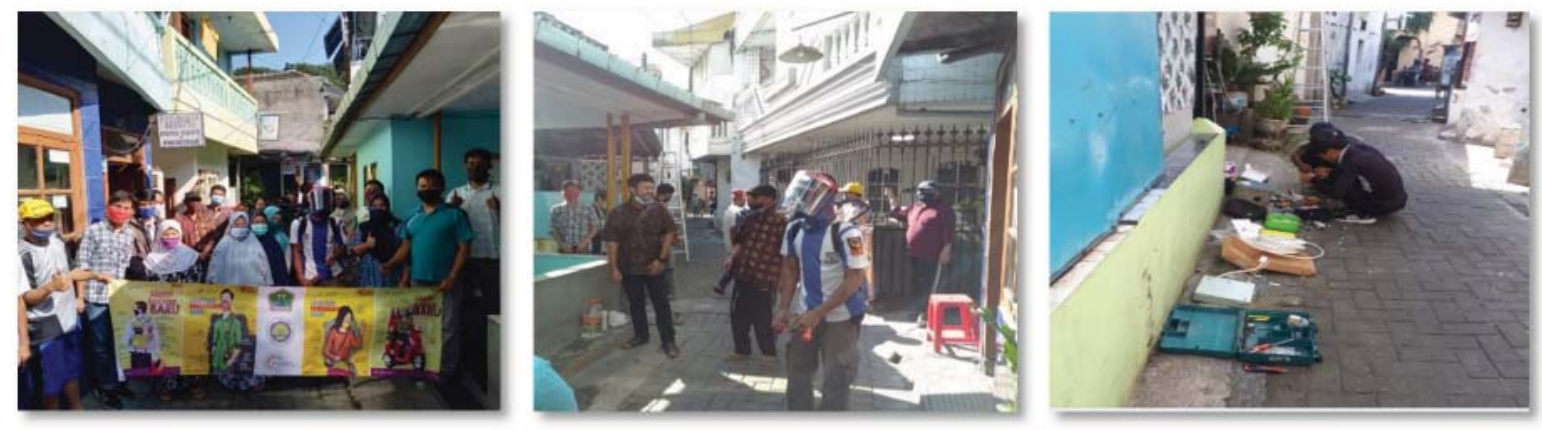

Gambar 2. Kegiatan pembukaan pengabdian RT 09 RW 06 Penanggungan Malang

Gambar 3. Persiapan pemasangan kamera CCTV
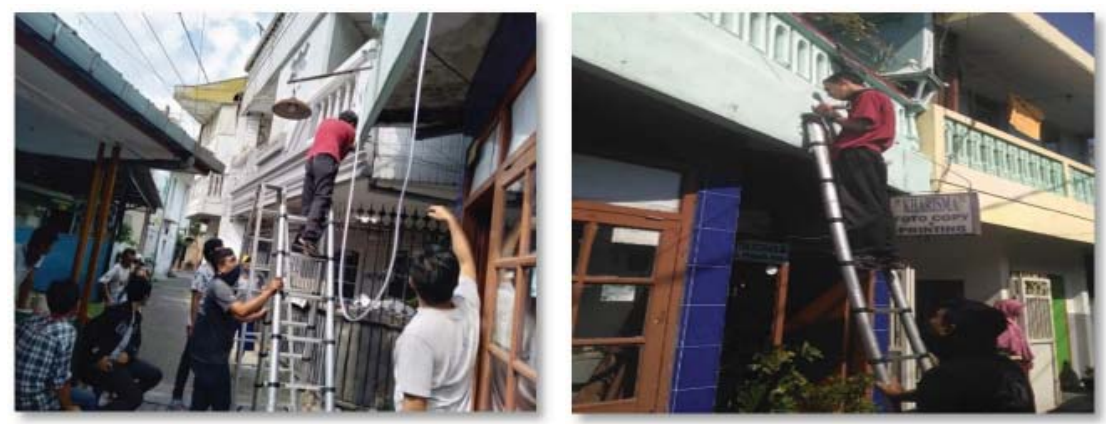

Gambar 4. Kegiatan pemasangan instalasi CCTV

\section{Tahap instalasi}

Pada tahap instalasi ini semua peralatan dan bahan yang dibutuhkan sudah siap digunakan. Kegiatan ini mulai dilaksanakan pada pukul 10.00-14.00 WIB. Terdapat 6 titik pemasangan kamera pengawas CCTV yaitu 1 kamera mengarah pada jalan masuk lingkungan yaitu gang IX Mayjend Panjaitan, 1 kamera menyorot ke arah keluar dari lingkungan dan mengarah keluar menuju jalan raya, 1 kamera 
Application of the Internet of Things (IOT) based digital platform for "Peduli, Keamanan, dan Ketertiban" (PEKERTI) Irham Fadlika, Arif Nur Afandi, Langlang Gumilar, Muhammad Rizal Andriansyah, Eka Mistakim, Achmad Syahrudin Fakhri, M. Ricko Gunawan

menyorot ke arah jalan masuk dari RT 7, kemudian 1 kamera menyorot ke arah jalan keluar gerbang $\mathrm{CL}$ Universitas Brawijaya, 1 kamera mengawasi ke arah lingkungan tengah dan 1 kamera terakhir mengawasi jalan tembus dari arah jalan Veteran. Setelah semua kamera pengawas berhasil dipasang, kemudian tahap selanjutnya adalah penarikan kabel dari setiap kamera CCTV ke control room. Setelah instalasi selesai dilakukan kemudian sekalian dilakukan uji coba CCTV yang sudah terpasang sudah terpasang dengan baik dan sudah dapat diakses melalui handphone warga. Kegiatan Instalasi ini dapat dilihat pada Gambar 4.

\section{Hasil produk kegiatan (Aplikasi PEKERTI)}

Logo Aplikasi PEKERTI ditunjukkan pada Gambar 5. Untuk dapat mengakses Aplikasi PEKERTI dari perangkat Android, mitra bersama warganya harus melakukan pendaftaran terlebih dahulu. Data yang dibutuhkan untuk login ke Aplikasi PEKERTI yaitu email aktif, password, nama sesuai KTP, Nomor Induk Kependudukan (NIK), alamat lengkap, dan kode daftar. Login diperlukan untuk mendaftarkan email ke server PEKERTI. Kemudian terdapat tiga kode daftar untuk mendaftar aplikasi ini, kode ini berupa angka 6-digit dimana setiap kode memiliki perbedaan pengguna dan perbedaan fitur yang dapat diakses dari Aplikasi PEKERTI. Ketiga kode ini adalah Admin, Warga, dan Anak Kost. Tampilan pendaftaran dan tampilan halaman awal Aplikasi PEKERTI masing-masing ditampilkan pada Gambar 6 dan 7.

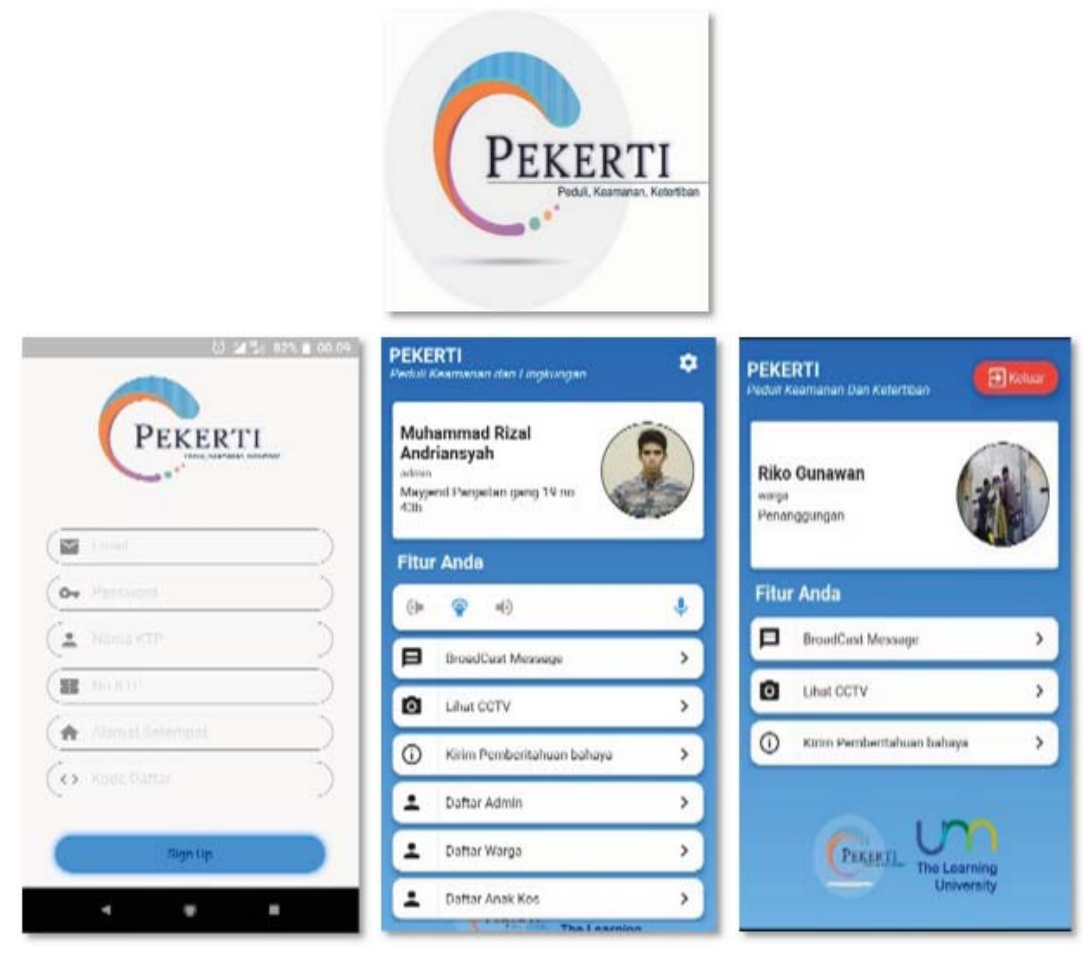

Gambar 5. Logo Aplikasi PEKERTI

Gambar 6. Tampilan pendaftaran Aplikasi PEKERTI

Gambar 7. Perbedaan tampilan awal warga dan admin

Gambar 8 menunjukkan fitur penting Aplikasi PEKERTI yang meliputi live preview CCTV dan pengiriman pesan indikasi bahaya. Masing-masing warga dapat memantau kejadian di sekitar lingkungannya dengan mengklik kamera mana yang ingin dipilih. Selain itu, pada gambar yang sama, 
ABDIMAS: Jurnal Pengabdian Masyarakat Universitas Merdeka Malang

Volume 7, No 1, February 2022: 54-63

admin dapat melakukan pengiriman pesan bahaya untuk memberi tahu warga lainnya apabila terjadi kondisi rawan kejahatan.

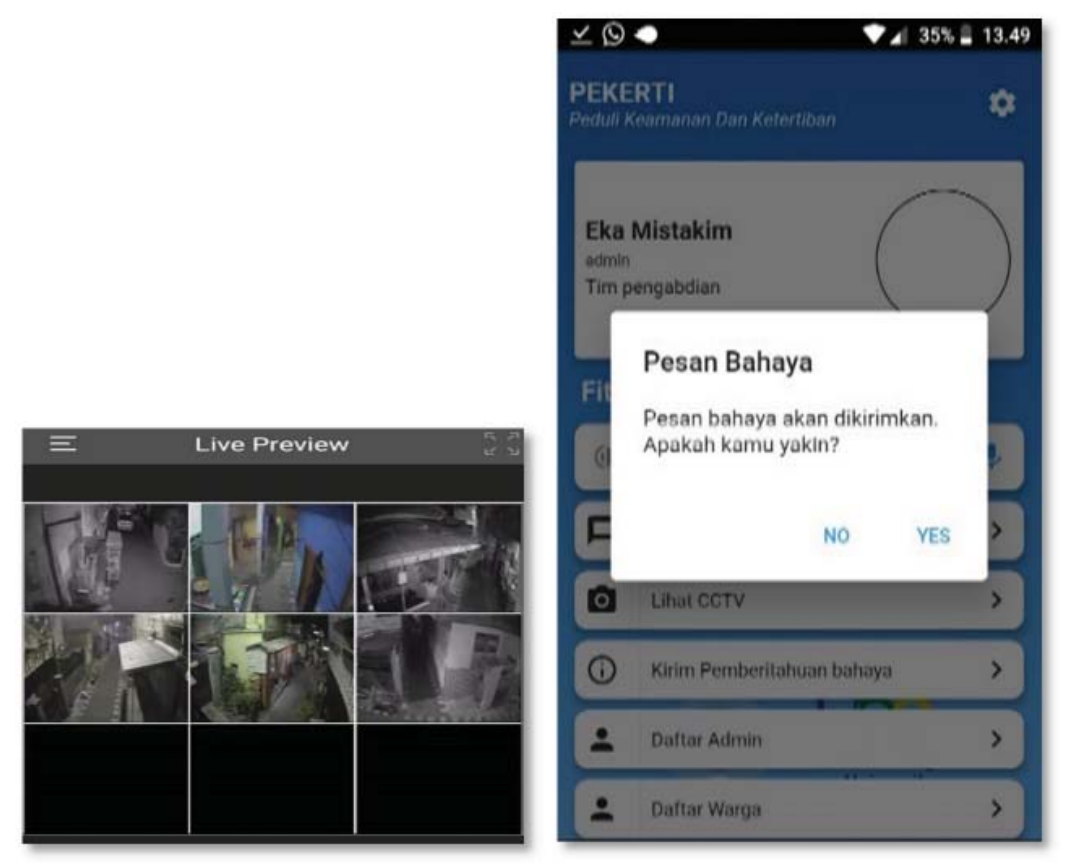

Gambar 8. Tampilan live preview kamera pengawas CCTV dan pesan bahaya

\section{Evaluasi kegiatan}

Sistem PEKERTI yang diajukan di area Penanggungan Kota Malang yang bertujuan untuk meningkatkan aktivitas kolektif antar warga dan kepedulian dalam menjaga keamanan membuat Ketua RT setempat merasa kegiatan pengabdian seperti ini sangat membantu dalam menjaga keamanan di lingkungan yang padat penduduk. Pembuatan aplikasi yang dapat memantau lingkungan dari smartphone merupakan trobosan yang masih baru bagi lingkungan mitra sehingga mitra dan warganya berharap dapat diteruskan ke lingkungan-lingkungan yang lain. Beberapa indikator dan capaian terkait kegiatan ini dijabarkan dalam ulasan.

\section{Survei sebelum dan sesudah adanya kegiatan pengabdian}

Kami melakukan survei sederhana kepada 30 warga RT 09 RW 06 Penanggungan untuk mengetahui seberapa besar pengaruh kegiatan ini. Terdapat 5 indikator yang menjadi penilaian yaitu tingkat Kepedulian, Keamanan, Kenyamanan, Ketertiban, dan Antusiasme dimana survei menggunakan skala interval 1-5 yang setiap angka mewakili pernyataan tidak baik, kurang baik, cukup baik, baik, dan sangat baik.

Dari Gambar 9 dapat dapat ditarik beberapa kesimpulan yaitu: (1) Tingkat kepedulian warga meningkat setelah adanya pemanfaatan Aplikasi PEKERTI dimana sebelum adanya pekerti bernilai 1,7 sedangkan setelah adanya aplikasi ini meningkat menjadi 3,9 yang artinya mendekati Baik; (2) Tingkat kenyamanan mitra dan warganya mengalami peningkatan dari yang awalnya bernilai 1,8 yang berarti mendekati kurang baik menjadi 3,9 yang artinya mendekati baik; (3) Terciptanya lingkungan yang aman dari pencurian dan perampokan di tengah pandemi hal ini terwujud dari pemasangan kamera pengawas CCTV dan dapat di-monitoring selama 24 jam hanya melalui smartphone terbukti dengan meningkatnya 
rasa aman warga dari yang sebelumnya bernilai 2,5 yang kurang baik menjadi 4,7 yaitu mendekati sangat baik; (4) Terlihat dari Gambar 9 tingkat ketertiban meningkat dari 2,0 kurang baik menjadi 4,1 yang artinya sudah baik; (5) Meningkatnya antusiasme untuk saling mengawasi dan memberi informasi dalam menjaga keamanan lingkungan dalam memantau CCTV yang terpasang dari telepon seluler masing-masing, tingkat antusiasme warga juga mengalami peningkatan dari angka 2,5 menjadi angka 4,0 yang artinya tingkat antusiasme warga menjadi baik.

\section{Survei efektifitas Aplikasi PEKERTI}

Setelah kegiatan awal pemasangan instalasi CCTV dan penginstalan Aplikasi PEKERTI pada tanggal 28 Juni 2020, masyarakat mayoritas sudah merasakan manfaat dari Aplikasi PEKERTI. Hal tersebut didukung dengan data kuisioner per akhir bulan Januari 2021 berdasarkan aktivitas warga selama 7 bulan pasca kegiatan pengabdian. Dari 30 warga Lingkungan Penanggungan Kota Malang, sebanyak 80\% menyatakan penggunaan Aplikasi PEKERTI ini sangat efektif, 17\% mengatakan efektif, 3\% warga menyatakan netral, dan tidak ada warga menyatakan penggunaan aplikasi ini kurang efektif dan tidak efektif. Bedasarkan Gambar 10 dapat disimpulkan bahwa 97\% warga menyatakan penggunaan Aplikasi PEKERTI ini sangat efektif dalam menjaga keamanan lingkungan ditengah pandemi. Selain untuk menjaga keamanan, PEKERTI juga meningkatkan tingkat kepedulian, kenyamanan, ketertiban warga.
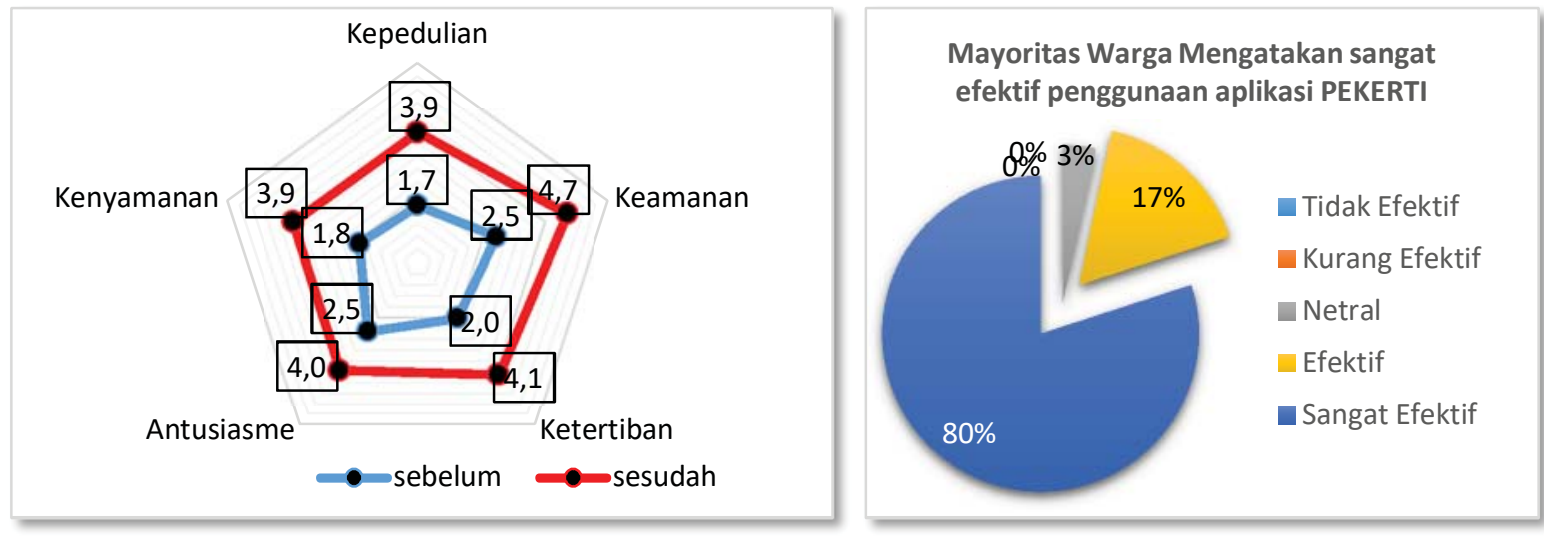

Gambar 9. Grafik sebelum dan sesudah pengabdian

Gambar 10. Presentase keefektifan Aplikasi PEKERTI

\section{Faktor pendukung}

Terdapat beberapa faktor yang mendukung mulusnya pelaksanaan program pengabdian ini, yaitu: (1) Mudahnya perizinan dari perangkat Desa Penanggungan dalam pelaksanaan kegiatan ini; (2) Masyarakat RT 09 RW 06 antusias mengikuti kegiatan ini mulai dari perencanaan sampai dengan instalasi CCTV; (3) Warga memberi dukungan dalam peralatan untuk kegiatan pemasangan; (4) Program pengabdian ini telah dijadwalkan dan terlaksana sesuai jadwal yang direncanakan; (5) Kondisi rumah mitra yang digunakan sebagai ruangan control room sudah memiliki Wi-Fi sehingga tidak menemui kendala dalam jaringan internet yang dibutuhkan.

\section{Faktor penghambat}

Dalam realisasi kegiatan pengabdian ini juga kami temui beberapa hambatan yang terjadi antara lain: (1) Pemilihan kamera yang digunakan sebagai kamera pengawas CCTV membutuhkan 
ABDIMAS: Jurnal Pengabdian Masyarakat Universitas Merdeka Malang

Volume 7, No 1, February 2022: 54-63

spesifikasi yang khusus sehingga dibutuhkan waktu yang relatif lama dalam menentukan jenis kamera yang digunakan; (2) Dikarenakan rumah warga yang rapat menyebabkan lama dalam menentukan titik-titik pemasangan kamera yang dapat memantau seluruh lingkungan dan berapa jumlah kamera yang dibutuhkan; (3) Kurangnya pengetahuan warga dan mitranya dalam platform digital berbasis IoT menyebabkan pemberian materi tentang perawatan membutuhkan waktu yang lama bagi masyarakat mitra.

\section{SIMPULAN DAN SARAN}

Kegiatan pengabdian masyarakat di lingkungan warga masyarakat RT 09 RW 06 Kelurahan Penanggungan Kecamatan Klojen Kota Malang telah dilakukan dengan baik sesuai jadwal kegiatan yang sudah dirancang oleh tim pengabdian. Hal ini terlihat dari telah terpasangnya kamera pengawas CCTV dan penggunaan Aplikasi PEKERTI di lingkungan mitra untuk menjaga keamanan lingkungan. Program pengabdian semacam ini sangat diperlukan masyarakat untuk menciptakan rasa kepedulian, aman, dan tertib bagi lingkungan, sehingga disarankan kegiatan semacam ini perlu untuk dilanjutkan dan menjangkau lebih banyak lingkungan padat penduduk terutama di sekitar lingkungan kampus.

Beberapa saran dari kegiatan ini di antaranya perlu adanya pengembangan lebih lanjut dari kegiatan ini, yaitu sosialiasi dan tutorial penggunaan aplikasi melalui video sehingga masyarakat lebih mudah dalam mengoperasikan Aplikasi PEKERTI, perlu adanya pembatasan jumlah pengguna admin karena saat ini semua bisa mendaftar sebagai admin hanya berdasarkan dari kode daftar, ini berguna untuk mengantisipasi ketika terjadinya double informasi yang disampaikan melalui pengeras suara, koordinasi lebih lanjut dengan pemangku kebijakan setempat guna memperluas fasilitas dan akses warga di RT lainnya.

\section{UCAPAN TERIMA KASIH}

Terima kasih yang sedalam-dalamnya kepada LP2M Universitas Negeri Malang yang telah memberikan dukungan penuh terhadap kegiatan ini melalui Anggaran PNPB Universitas Negeri Malang Nomor 3.3.16/un32/KP/2020 tanggal 3 Maret 2020 melalui Surat Keputusan Rektor Universitas Negeri Malang dalam Pelaksanaan Program Pengabdian Kepada Masyarakat untuk skema program Kemitraan Masyarakat Lingkungan Kampus.

\section{DAFTAR PUSTAKA}

Al Rasyid, M. U. H., Saputra, F. A., \& Kurniawan, A. (2020, September). Surveillance monitoring system based on internet of things. In 2020 International Electronics Symposium (IES), 588-593. https:// doi.org/10.1109/IES50839.2020.9231634

Dede, M., Sugandi, D., \& Setiawan, I. (2019). Interaksi spasial kondisi sosial-ekonomi terhadap kerawanan kejahatan di Kota Bandung (Studi kasus Sumur Bandung). Jambura Geoscience Review, 1(2), 40-49. https://doi.org/10.34312/jgeosrev.v1i2.1756

Doni, F. R. (2020). Akses kamera CCTV dari jarak jauh untuk monitoring keamanan dengan penerapan PSS. EVOLUSI/: Jurnal Sains dan Manajemen, 8(1), 1-9. https://doi.org/10.31294/evolusi.v8i1.7142

Gozali, F., \& Basori, Y. I. (2016). Sistem keamanan lingkungan perumahan berbasis web menggunakan Raspberry Pi. Jetri: Jurnal Ilmiah Teknik Elektro, 14(1), 35-48. 
Karinda, C. N., Najoan, X. B. N., \& Najoan, M. E. I. (2021). Perancangan dan implementasi loT dalam memantau keamanan lingkungan berbasis aplikasi mobile dan Rasspberry Pi. Jurnal Teknik Informatika, 16(2), 193-202. https://doi.org/10.35793/jti.16.2.2021.34166

Mufidah, U. A. (2021). Tinjauan kriminologis tentang pencurian kendaraan bermotor selama pandemi di Polres Malang. Dinamika: Jurnal Ilmiah Ilmu Hukum, 27(10), 1405-1423.

Mustolih, I. (2019). Program polisi mitra rukun warga dalam mewujudkan keamanan dan ketertiban masyarakat di Polres Kota Malang. Jurnal Sosiologi Dialektika, 14(1), 52-58. http://dx.doi.org/10.20473/jsd.v14i1.2019.52-58

Oktavia, H. (2020, Desember 29). Angka curanmor di Kota Malang tertinggi selama 2020. Rri.Co.Id.

Pramesti, K. A. D. W., \& Suardana, I. W. (2019). Faktor penyebab dan upaya penanggulangan tindak pidana pencurian kendaraan bermotor (curanmor) di Kota Denpasar. Kertha Wicara: Journal Ilmu Hukum, 9(2), 1-16.

Purnomo, H. D. (2019). Peran Tim Anti Bandit Satreskrim Polrestabes Surabaya dalam penanggulangan tindak pidana kejahatan jalanan. Jurnal Sosiologi Dialektika, 14(1), 34-43.

http://dx.doi.org/10.20473/jsd.v14i1.2019.34-43

Puspitasari, D., Hamdana, E. N., \& Putra, M. Y. P. (2019). Pengembangan sistem pengukuran korelasi antara tingkat pengangguran terbuka terhadap tingkat kriminalitas di Kota Malang. Seminar Informatika Aplikatif Polinema, 150-155.

Ramayani, T., Kurniawan, B., Wulandari, F., Rozi, F., \& Prabowo, C. (2018). Penerapan loT (Internet Of Things) untuk pencegahan dini terhadap kejahatan begal. Jurnal RESTI (Rekayasa Sistem Dan Teknologi Informasi), 2(3), 627-632. https://doi.org/10.29207/resti.v2i3.552

Sugiarti, Y. (2014). Kemiskinan sebagai salah satu penyebab timbulnya tindak kejahatan. Jendela Hukum, 1(1).

Sutejo, D., Pranoto, Y. A., \& Zahro, H. Z. (2020). Sistem informasi geografis pengelompokan tingkat kriminalitas Kota Malang menggunakan Metode K-Means. JATI (Jurnal Mahasiswa Teknik Informatika), 4(1), 356-363. https://doi.org/10.36040/jati.v4i1.2315

Tarwanto, A., \& Arinal, V. (2021). Implementasi dan monitoring sistem keamanan kendaraan berbasis IoT pada Bengkel Cahaya. SOSTECH: Jurnal Sosial dan Teknologi, 1(8), 887-892. https://doi.org/10.36418/jurnalsostech.v1i8.176

Tutrianto, R. (2018). Munculnya wilayah kejahatan di Perkotaan (Studi pada Kota Pekanbaru). Indonesian Journal of Criminology, 14(1), 267428.

Wardani, L. K., Endri, J., \& Lindawati. (2021). Aplikasi monitoring tamu pada sistem keamanan perumahan komplek berbasis Android. J-SAKTI: Jurnal Sains Komputer dan Informatika, 5(2), 957-963. http://dx.doi.org/10.30645/j-sakti.v5i2.391

Yutanto, H., Sihotang, E. T., Wulanditya, P., \& Diptyana, P. (2020). Sosialisasi pembayaran iuran dan monitoring SiWarga berbasis teknologi pada Perumahan Griya Pesona Asri Surabaya. Abdimas: Jurnal Pengabdian Masyarakat Universitas Merdeka Malang, 5(2), 168-179. https://doi.org/10.26905/abdimas.v5i2.4347

Zamroni, K., \& Ghafur, A. (2016). Strategi humas Polresta Malang dalam sosialisasi kewaspadaan masyarakat pada isu tindak kriminal begal. Jurnal Ilmu Sosial dan Ilmu Politik, 5(3), 89-92. https://doi.org/10.33366/jisip.v5i3.251 